\title{
Effects of intraruminal urea-nitrogen infusions on feed intake, nitrogen utilization, and milk yield in dairy cows
}

\author{
S. Ahvenjärvi* and P. Huhtanen† \\ *Natural Resources Institute Finland (Luke), Milk Production, Fl-31600 Jokioinen, Finland \\ †Department of Agricultural Research for Northern Sweden, Swedish University of Agricultural Sciences (SLU), S-90183 Umeå, Sweden
}

\begin{abstract}
The objective of this study was to determine the effects of supplementation of protein deficient diet with increasing amounts of urea- $\mathrm{N}$ on feed intake, milk yield, rumen fermentation, and nutrient digestibility in dairy cows. The hypothesis was that low rumen ammonia- $\mathrm{N}$ concentrations provide suboptimal conditions for rumen microbes and these conditions can be alleviated by urea- $\mathrm{N}$ that increases rumen ammonia$\mathrm{N}$ concentrations. To evaluate this hypothesis, the diet was formulated slightly deficient with respect to rumen-degradable protein. To supplement the diet with rumen degradable $\mathrm{N}, 5$ levels of urea- $\mathrm{N}(0,17,33,49$, and $66 \mathrm{~g} / \mathrm{d}$ ) were continuously infused into the rumen of 5 dairy cows according to a $5 \times 5$ Latin square. Increasing levels of urea- $\mathrm{N}$ infusion increased $\mathrm{N}$ intake and $\mathrm{N}$ excretion in urine and feces in a linear manner and tended to increase milk and milk protein yields. Feed intake and fiber digestibility were not affected by urea- $\mathrm{N}$ infusion levels. Rumen ammonia- $\mathrm{N}$ concentrations remained low $(3.5 \mathrm{mg} / 100 \mathrm{~mL})$ and did not respond to urea-N infusions levels between 0 to $49 \mathrm{~g} / \mathrm{d}$, whereas the highest level of urea-N $(66 \mathrm{~g} / \mathrm{d})$ increased rumen ammonia- $\mathrm{N}$ concentration to $5.1 \mathrm{mg} / 100 \mathrm{~mL}$ (quadratic effect). These observations suggested that rumen microbes efficiently captured ammonia- $\mathrm{N}$ from rumen fluid until sufficient intracellular ammonia-N concentrations were attained, after which ammonia$\mathrm{N}$ concentrations started to increase in extracellular rumen fluid. In contrast, milk urea- $\mathrm{N}$ concentrations increased in a curvilinear manner (cubic effect) from 4.4 to around $6 \mathrm{mg} / 100 \mathrm{~mL}$ for the medium levels of urea- $\mathrm{N}$ and then to $7.9 \mathrm{mg} / 100 \mathrm{~mL}$ for the highest level of urea-N infusion. The current results indicated that $18 \%$ of supplementary $\mathrm{N}$ intake was secreted in milk
\end{abstract}

Received February 21, 2018.

Accepted June 25, 2018.

${ }^{1}$ Corresponding author: seppo.ahvenjarvi@luke.fi and $53 \%$ in urine. In spite of low rumen ammonia-N concentrations observed for the basal diet, it was estimated that only $43 \%$ of supplementary $\mathrm{N}$ was captured by rumen microbes. Estimated true digestibility for supplementary N $(93 \%)$ provided further evidence that urea-N stimulated microbial $\mathrm{N}$ synthesis. The current results indicate that rumen ammonia- $\mathrm{N}$ concentration was an insensitive indicator of $\mathrm{N}$ deficiency at low levels of diet $\mathrm{CP}$, whereas milk urea- $\mathrm{N}$ was responsive to diet $\mathrm{CP}$ concentrations at all urea-N infusion levels.

Key words: urea, dairy cow, nitrogen, rumen

\section{INTRODUCTION}

The main principle in formulation of diets for dairy cows has been to provide a ration that allows individuals to satisfy their nutritional requirements. In an attempt to account for the $\mathrm{N}$ requirements of the rumen microbes and protein requirements of the cow, a distinction between RDP and RUP has been made in the current feed evaluation systems. However, the success of assigning dietary protein to these 2 fractions has been meager (Schwab et al., 2005). Arguably, dairy cows do not have absolute requirements for the amount of MP because they can adapt to different levels of nutrition by adjusting their feed intake and milk yield as required to maintain a balance between nutrient supply and body requirements (Vérité and Delaby, 2000; Huhtanen et al., 2011b). The optimum amount of CP in the diet depends on definition because the optimum for milk yield is often very different from the optimum for N use efficiency (Huhtanen et al., 2011a). Supplementation of dairy cow diets with protein feeds has often resulted in positive production responses in terms of milk and milk protein yield (Vérité and Delaby, 2000; Ipharraguerre and Clark, 2005; Huhtanen et al., 2011a). In spite of positive milk yield responses to increases in $\mathrm{CP}$ intake, the $\mathrm{N}$ use efficiency (milk $\mathrm{N} / \mathrm{N}$ intake) has consistently decreased (Castillo et al., 2001; Nursoy et al., 2018). The main reason for such decreases is that a large proportion of feed protein is degraded in the rumen and only a small proportion enters the omasal 
canal as undegradable feed protein (Broderick et al., 2010). Furthermore, increasing the MP to energy ratio above recommendations resulted in linear increases in urine $\mathrm{N}$ excretion but only minor increases in milk yield (Vérité and Delaby, 2000). Attempts to increase the proportion of RUP in protein feeds have often been successful in enhancing ruminal outflow of nonammonia $\mathrm{N}$, but the effects on milk $\mathrm{CP}$ yield have been minor and sometimes even negative (Ipharraguerre and Clark, 2005). Feeding a diet that provides RDP in excess of microbial needs will inevitably decrease the $\mathrm{N}$ use efficiency (Broderick, 2003; Huhtanen and Hristov, 2009) but even maintaining the $\mathrm{N}$ use efficiency using supplements enriched with RUP seems unrealistic. This has been convincingly demonstrated by studies in which supplementary protein was supplied directly into the abomasum of dairy cows (Choung and Chamberlain, 1993; Guinard et al., 1994). In both studies lowest levels of casein or soya protein isolate infused into the abomasum were efficiently used for milk protein synthesis and either improved or maintained the $\mathrm{N}$ use efficiency of the basal diet. However, higher amounts of either casein or soya protein resulted in diminishing utilization for milk protein synthesis (Choung and Chamberlain, 1993; Guinard et al., 1994). In practice such utilization rates of supplementary protein, as achieved using abomasal casein infusions, cannot be attained because of inevitable degradation losses in the rumen, lower intestinal CP digestibility, and less ideal AA composition of RUP supplements. Arguably, the most efficient means of improving the $\mathrm{N}$ use efficiency in milk production is to formulate a diet that provides sufficient RDP for rumen microbes but avoids excess supply that is metabolized to ammonia-N, absorbed from the digestive tract, and lost in urine (Huhtanen and Hristov, 2009). A previous study in lactating dairy cows given pulse doses of ${ }^{15} \mathrm{~N}$ labeled ammonia- $\mathrm{N}$ and grass silage soluble $\mathrm{N}$ indicated that 53 and $62 \%$, respectively, of rumen bacterial $\mathrm{N}$ was derived from rumen ammonia-N pool (Ahvenjärvi et al., 2018). These observations suggest that rumen ammonia- $\mathrm{N}$ pool plays an important role in rumen $\mathrm{N}$ dynamics and NPN sources could be used to complement deficiencies in RDP supply.

The objective of the current study was to assess the critical diet $\mathrm{CP}$ and rumen ammonia-N concentrations, below which the microbial $\mathrm{N}$ synthesis and fiber digestibility are decreased relative to the optimal conditions. The hypothesis underlying the current study was that feed intake, nutrient digestibility, and milk yield of lactating dairy cows are compromised when offered a diet formulated slightly deficient in terms of RDP. The hypothesis further assumed that suboptimal rumen conditions could be improved by urea- $\mathrm{N}$ infusions into the rumen that increase rumen ammonia-N concentrations.

\section{MATERIALS AND METHODS}

\section{Animals, Diet, and Experimental Design}

The current experiment was conducted in compliance with the Finnish Act on the Use of Animals for Experimental Purposes and experimental procedures were approved by the National Animal Experiment Board. The effects of intraruminal urea- $\mathrm{N}$ infusions were investigated using 5 lactating dairy cows that received a basal diet formulated marginally deficient of RDP. Grass silage was provided as forage because it is the most widely cultivated forage crop in Northern Europe. In addition, our previous study (Ahvenjärvi et al., 2018) indicated that a pulse dose of ammonia- $\mathrm{N}$ introduced into the rumen of dairy cows fed grass silage-based diet was efficiently used for microbial $\mathrm{N}$ synthesis. Experimental animals were multiparous Finnish Ayrshire dairy cows equipped with $10 \mathrm{~cm}$ i.d. rumen cannulas (Bar Diamond Inc., Parma, ID). The cows were on average 77 DIM (SD 12.3) at the beginning of the experiment and weighed $620 \mathrm{~kg}$ (SD 35.6). The basal diet was offered 4 times daily at 0600,0900, 1800, and $2000 \mathrm{~h}$ according to appetite allowing at least $5 \%$ for the daily refusals. Silage was prepared from a primary growth of a mixture of timothy (Phleum pratense) and meadow fescue (Festuca pratensis) grass species. Grass was cut and conditioned using a mower-conditioner and allowed to wilt for a few hours before it was harvested using a precision chopper. To restrict the extent of silage fermentation, silage additive [AIV 2 Plus (Formic acid $77 \%$, Ammonium formate 5.5\%) Taminco Finland Oy, Oulu, Finland] was applied onto grass at harvest at a rate of $5 \mathrm{~L} / \mathrm{t}$. Grass was ensiled in bunker silos until mixed with concentrates to prepare TMR that contained (per $\mathrm{kg}$ of DM) $511 \mathrm{~g}$ of grass silage, $156 \mathrm{~g}$ of wheat, $152 \mathrm{~g}$ of oats, $147 \mathrm{~g}$ of molassed sugar beet pulp, $20 \mathrm{~g}$ of solvent-extracted rapeseed meal, and $15 \mathrm{~g}$ of mineral and vitamin premix (Rehumelica Oy, Vaasa, Finland).

The experimental treatments consisted of 5 levels of urea-N $(0,17,33,49$, and $66 \mathrm{~g} / \mathrm{d}$ of N; Sigma-Aldrich Chemie GmbH, Steinheim, Germany) dissolved in $6 \mathrm{~L}$ of water and infused into the rumen through a rumen cannula using a peristaltic pump (Watson-Marlow 502 $\mathrm{S}$, Falmouth, UK). Urea-N was administered by means of water infusion to avoid palatability problems often encountered with urea-N-containing diets and to ensure constant daily doses. Treatments were randomly allocated to each cow according to a $5 \times 5$ Latin square 
change-over design. The experiment consisted of 5 periods each that lasted for $14 \mathrm{~d}$. Feed intake recorded from d 10 to 14 was used to compare treatment effects.

\section{Sampling Procedures}

Nutrient digestibility and $\mathrm{N}$ excretion in urine were determined based on total collection of feces and urine conducted over $3 \mathrm{~d}$ from d 11 to 13 of each period. Rumen ammonia-N and VFA concentrations were determined on d 14 based on 8 samples collected at 1.5-h intervals from 0600 to $1630 \mathrm{~h}$. Rumen fluid samples of approximately $200 \mathrm{~mL}$ were aspirated via the rumen cannula using a perforated plastic tube. Samples were immediately filtered through one layer of cheesecloth and measured for pH. For VFA analysis, $5.0 \mathrm{~mL}$ of rumen fluid was treated with $0.5 \mathrm{~mL}$ of saturated $\mathrm{HgCl}_{2}$ and $2.0 \mathrm{~mL}$ of $1 \mathrm{M} \mathrm{NaOH}$ solution. For ammonia-N analysis, $0.3 \mathrm{~mL}$ of $50 \% \mathrm{H}_{2} \mathrm{SO}_{4}$ was added to $15 \mathrm{~mL}$ of rumen fluid. Samples were stored at $-20^{\circ} \mathrm{C}$ until analyzed. Milk yields measured from d 10 to 14 daily were used to compare treatment effects. Milk composition and MUN concentrations were analyzed from samples collected from 4 consecutive milkings from d 11 to 13 .

\section{Chemical Analysis}

Feed and fecal samples were dried in a forced-air oven at $60^{\circ} \mathrm{C}$ and milled for chemical analysis using a cutter mill with a 1-mm screen. Residual DM concentration of dried and ground samples was determined in a forcedair oven at $105^{\circ} \mathrm{C}$ for $16 \mathrm{~h}$. Silage DM concentration was corrected for the loss of volatile compounds as described by Huida et al. (1986). Ash concentration was determined in a muffle furnace according to AOAC method 942.05 (AOAC International, 2012). Nitrogen concentration in fresh samples of feces and urine was determined by the Kjeldahl method using $\mathrm{CuSO}_{4}$ as a catalyst. Nitrogen concentration in dry feed samples was determined using a Dumas-type elemental $\mathrm{N}$ analyzer (Leco FP-428, Leco Corporation, St. Joseph, MI). Starch concentration in feed ingredients was determined as described by Salo and Salmi (1968). The NDF concentration was analyzed in the presence of $\mathrm{Na}_{2} \mathrm{SO}_{3}$ using crucibles as described by Van Soest et al. (1991). Heat-stable $\alpha$-amylase was used for starchcontaining samples. Indigestible NDF in feeds and feces was determined based on 12-d in situ incubations in the rumen of dairy cows as described by Ahvenjärvi et al. (2006). Grass silage OM digestibility was determined based on pepsin-cellulase OM solubility as described by Nousiainen et al. (2003) and modified by Huhtanen et al. (2006). Concentration of digestible OM (D-value, g/ $\mathrm{kg}$ of DM) in grass silage was estimated using the equation proposed by Huhtanen et al. (2006): D-value (g/kg of $\mathrm{DM})=[1000-\operatorname{ash}(\mathrm{g} / \mathrm{kg}$ of $\mathrm{DM})] \times[0.077+0.86$ $\times$ OM solubility $(\mathrm{g} / \mathrm{g}$ of $\mathrm{OM})]$. Milk urea-N concentration was calculated from a difference in ammonia- $\mathrm{N}$ concentration between unhydrolyzed sample and that hydrolyzed with urease. Ammonia-N concentrations in rumen fluid were determined by direct colorimetric method (McCullough, 1967). Volatile fatty acid concentrations in grass silage and rumen fluid were determined by GC as described by Huhtanen et al. (1998). Concentrations of lactic acid and water-soluble carbohydrates in grass silage were determined as described by Haacker et al. (1983) and Somogyi (1945), respectively. Ethanol concentration was measured with an enzymatic kit (catalog no. 981680, KONE Instruments Corporation, Espoo, Finland) using the selective clinical chemistry analyzer Pro 981489 (KONE Instruments Corporation). Milk samples were analyzed for $\mathrm{CP}$, fat, and lactose concentration using an infrared milk analyzer (MilkoScan 133B, Foss Electric, Hillerod, Denmark). Milk true protein concentration was calculated as milk $\mathrm{CP} \%-(\mathrm{MUN} \% \times 6.38)$.

\section{Statistical Analysis}

Experimental data were analyzed using PROC MIXED of SAS 9.2 software (SAS Institute Inc., Cary, $\mathrm{NC})$. The effect of urea-N treatment on feed intake, digestibility, milk yield and composition, and rumen fermentation was estimated using the following model:

$$
\mathrm{Y}_{\mathrm{ijk}}=\mu+\mathrm{A}_{\mathrm{i}}+\mathrm{P}_{\mathrm{j}}+\mathrm{U}_{\mathrm{k}}+\varepsilon_{\mathrm{ijk}},
$$

where $\mu$ is the overall mean; $A_{i}$ is the random effect of animal; $\mathrm{P}_{\mathrm{j}}$ and $\mathrm{U}_{\mathrm{k}}$ are the fixed effects of period and urea-N treatment, respectively; and $\varepsilon_{\mathrm{ijk}}$ is the residual variation. Sums of squares were further separated using orthogonal contrasts into single degree of freedom comparisons to test the significance of linear, quadratic, and cubic effects of urea- $\mathrm{N}$ infusion levels.

The effects of urea-N treatment on rumen ammonia$\mathrm{N}$ concentrations were evaluated using a model for repeated measurements with first-order autoregressive covariance structure:

$$
\begin{aligned}
\mathrm{Y}_{\mathrm{ijkl}=\mu} & +\mathrm{A}_{\mathrm{i}}+\mathrm{P}_{\mathrm{j}}+\mathrm{U}_{\mathrm{k}}+\mathrm{A}_{\mathrm{i}} \times \mathrm{P}_{\mathrm{j}} \times \mathrm{U}_{\mathrm{k}}+\mathrm{T}_{1}+\mathrm{A}_{\mathrm{i}} \\
& \times \mathrm{T}_{\mathrm{l}}+\mathrm{P}_{\mathrm{j}} \times \mathrm{T}_{\mathrm{l}}+\mathrm{U}_{\mathrm{k}} \times \mathrm{T}_{1}+\mathrm{e}_{\mathrm{ijk} \mathrm{k}},
\end{aligned}
$$

where $\mu, A_{i}, P_{j}$, and $U_{k}$ are as previously described; $T_{1}$ is the sampling time; $A_{i} \times P_{j} \times U_{k}, A_{i} \times T_{1}, P_{j} \times T_{1}$, and $\mathrm{U}_{\mathrm{k}} \times \mathrm{T}_{\mathrm{l}}$ are the interactions; and $\mathrm{e}_{\mathrm{ijk} \mathrm{l}}$ is the residual variation. 
Table 1. Chemical composition of grass silage and concentrate ingredients

\begin{tabular}{|c|c|c|c|c|c|c|c|}
\hline Item & $\begin{array}{l}\text { Grass } \\
\text { silage }^{1}\end{array}$ & Wheat & Oats & $\begin{array}{l}\text { Sugar } \\
\text { beet pulp }\end{array}$ & $\begin{array}{l}\text { Rapeseed } \\
\text { meal }\end{array}$ & $\begin{array}{c}\text { Mineral and } \\
\text { vitamin premix }\end{array}$ & TMR \\
\hline $\mathrm{DM}, \mathrm{g} / \mathrm{kg}$ & 259 & 855 & 853 & 892 & 912 & 996 & 395 \\
\hline \multicolumn{8}{|l|}{ Composition, $\mathrm{g} / \mathrm{kg}$ of $\mathrm{DM}$} \\
\hline $\mathrm{N}$ & 22.6 & 16.5 & 18.8 & 18.1 & 60.2 & 0.5 & 20.3 \\
\hline NDF & 523 & 112 & 265 & 314 & 260 & $\mathrm{NA}^{3}$ & 364 \\
\hline $\mathrm{iNDF}^{4}$ & 66 & 12 & 115 & 20 & 112 & NA & 58 \\
\hline
\end{tabular}

${ }^{1}$ Fermentation quality: $\mathrm{pH}$ 4.0; in DM, g/kg: lactic acid 63, acetic acid 20, propionic acid 0.2, butyric acid 0.5, ethanol 6.9, water-soluble carbohydrates 74; in total $\mathrm{N}, \mathrm{g} / \mathrm{kg}$ : soluble $\mathrm{N} 621$, ammonium-N 55 .

${ }^{2}$ Mineral and vitamin composition: Ca, $205 \mathrm{~g} / \mathrm{kg} ; \mathrm{P}, 27 \mathrm{~g} / \mathrm{kg} ; \mathrm{Na}, 85 \mathrm{~g} / \mathrm{kg} ; \mathrm{Mg}, 75 \mathrm{~g} / \mathrm{kg}$; vitamin A, 120,000 IU $/ \mathrm{kg} ;$ vitamin D 3 , 25,000 IU $/ \mathrm{kg}$; vitamin E, $340 \mathrm{mg} / \mathrm{kg} ; \mathrm{Mn}, 350 \mathrm{mg} / \mathrm{kg}$; Zn, 1,460 mg/kg; Cu, $270 \mathrm{mg} / \mathrm{kg} ; \mathrm{I}, 39 \mathrm{mg} / \mathrm{kg}$; Co, $27 \mathrm{mg} / \mathrm{kg}$; and Se, $20 \mathrm{mg} / \mathrm{kg}$.

${ }^{3} \mathrm{NA}=$ not analyzed.

${ }^{4}$ Indigestible neutral detergent fiber.

\section{RESULTS}

\section{Chemical Composition of Feeds}

Chemical composition of feed ingredients and TMR are presented in Table 1. Grass silage for the current study was prepared with an objective of high digestibility $(707 \mathrm{~g} / \mathrm{kg}$ of DM of digestible OM) with moderate $\mathrm{CP}$ concentration $(141 \mathrm{~g} / \mathrm{kg}$ of DM). The fermentation characteristics of grass silage were typical for slightly wilted grass (DM concentration $259 \mathrm{~g} / \mathrm{kg}$ ) ensiled in a bunker silo using formic acid preservatives. The concentration of water-soluble carbohydrates was high in grass silage, whereas that of fermentation acids was low $(84 \mathrm{~g} / \mathrm{kg}$ of DM) with lactic acid being the predominant component ( $74 \%$ of total acids). Wheat, oats, and sugar beet pulp were selected as concentrate ingredients to formulate a highly digestible ration with moderate $\mathrm{CP}$ concentration. Rapeseed meal was included in TMR to adjust the $\mathrm{CP}$ to the targeted concentration of $130 \mathrm{~g} /$ $\mathrm{kg}$ of DM. Owing to slightly lower CP concentration of grass silage offered to the cows than determined before the experiment the $\mathrm{CP}$ concentration of the basal diet was $127 \mathrm{~g} / \mathrm{kg}$ of DM. According to the Finnish feed evaluation system (Finnish Feed Tables and Nutrient Requirements, 2018), the basal diet provided slightly less RDP than required by the rumen microbes with estimated rumen CP balance of $-58 \mathrm{~g} / \mathrm{d}$ (SD 13) or $-2.6 \mathrm{~g} / \mathrm{kg}$ of DM (SD 0.5). Supplementary N provided as urea- $\mathrm{N}$ increased the diet $\mathrm{CP}$ concentration from 127 to $131,136,140$, and $145 \mathrm{~g} / \mathrm{kg}$ of DM for the urea-N infusion levels of $17,33,49$, and $66 \mathrm{~g} / \mathrm{d}$, respectively. As predicted based on the Finnish feed evaluation system, the amount of MP provided by the basal diet was equal to the estimated MP requirements (MP intake - MP requirement $=-1 \mathrm{~g} / \mathrm{d}$; SEM 42 ) when a reduction in rumen microbial $\mathrm{CP}$ synthesis was assumed to be equal to the negative rumen $\mathrm{CP}$ balance. However, urea- $\mathrm{N}$ in- fusions did not have an effect (linear effect $P=0.38$ ) on estimated MP balance (MP intake - MP requirement) because MP requirements tended to increase $(P=0.08)$ as a result of a tendency for increases in milk yield.

\section{Feed Intake and Milk Yield}

The level of urea-N infusion had no effect on DM, $\mathrm{OM}$, digestible $\mathrm{OM}$, or NDF intake or digestibility of these chemical components (Table 2). Nitrogen intake from the basal diet was not affected by the treatment, but urea- $\mathrm{N}$ infusions increased total $\mathrm{N}$ intake $(P<$ $0.01)$, and $\mathrm{N}$ excreted in urine $(P<0.01)$ and feces $(P$ $=0.05)$ in a linear manner. Increases in fecal $\mathrm{N}$ output were associated with increases in fecal $\mathrm{N}$ concentrations $(P=0.02)$. Urea- $\mathrm{N}$ infusions tended to decrease the $\mathrm{N}$ use efficiency (linear effect, $P=0.07$ ). The $\mathrm{N}$ balance of cows was slightly positive for the lower levels of urea- $\mathrm{N}$ infusion ( 0 to $49 \mathrm{~g}$ of urea- $\mathrm{N}$ ) but increased for the highest urea-N level as indicated by the significant cubic effect for the urea-N infusions $(P=0.04)$.

Milk yield $(P=0.08)$, milk CP yield $(P=0.08)$, and true protein yield $(P=0.10)$ tended to respond in a linear manner to increasing levels of urea- $\mathrm{N}$ infusions (Table 3). Milk urea-N concentrations increased in a curvilinear manner (cubic effect, $P=0.05$ ) from 4.4 $\mathrm{mg} / 100 \mathrm{~mL}$ for the lowest level of urea- $\mathrm{N}$ infusion to around $6 \mathrm{mg} / 100 \mathrm{~mL}$ for the medium levels of infusion (17 to $49 \mathrm{~g} / \mathrm{d}$ ), followed by a substantial increase up to $7.9 \mathrm{mg} / 100 \mathrm{~mL}$ for the highest level of infusion $(66 \mathrm{~g} / \mathrm{d})$. No significant effects on ECM, fat or lactose yield, or milk composition were observed.

\section{Rumen Fermentation}

Ruminal ammonia- $\mathrm{N}$ concentrations exhibited postprandial peaks at $1.5 \mathrm{~h}$ after the $0600 \mathrm{~h}$ meal that 
Table 2. Effects of urea infusion on feed intake and nutrient digestibility

\begin{tabular}{|c|c|c|c|c|c|c|c|c|c|}
\hline Item & \multicolumn{5}{|c|}{ Urea infusion level, $\mathrm{g} / \mathrm{d}$} & SEM & \multicolumn{3}{|c|}{ Orthogonal contrast } \\
\hline \multicolumn{10}{|l|}{ Nutrient intake, $\mathrm{kg} / \mathrm{d}$} \\
\hline $\mathrm{OM}$ & 20.4 & 20.6 & 20.4 & 20.5 & 21.2 & 0.76 & 0.35 & 0.46 & 0.57 \\
\hline Digestible OM & 14.2 & 14.5 & 14.3 & 14.4 & 14.9 & 0.56 & 0.31 & 0.62 & 0.47 \\
\hline $\mathrm{NDF}$ & 8.20 & 8.26 & 8.18 & 8.24 & 8.52 & 0.305 & 0.35 & 0.44 & 0.59 \\
\hline \multicolumn{10}{|l|}{ Nutrient digestibility, $\mathrm{kg} / \mathrm{kg}$} \\
\hline $\mathrm{OM}$ & 0.694 & 0.704 & 0.701 & 0.700 & 0.703 & 0.0056 & 0.35 & 0.56 & 0.31 \\
\hline NDF & 0.549 & 0.559 & 0.562 & 0.559 & 0.564 & 0.0111 & 0.31 & 0.61 & 0.58 \\
\hline $\mathrm{N}$ & 0.614 & 0.625 & 0.612 & 0.603 & 0.612 & 0.0075 & 0.32 & 0.99 & 0.09 \\
\hline \multicolumn{10}{|l|}{$\mathrm{N}$ excretion } \\
\hline In urine, $\mathrm{g} / \mathrm{d}$ & 109 & 119 & 131 & 145 & 151 & 5.1 & $<0.01$ & 0.81 & 0.56 \\
\hline
\end{tabular}

reached 9.2 to $9.8 \mathrm{mg} / 100 \mathrm{~mL}$ for all urea- $\mathrm{N}$ infusion levels (Figure 1). After the peak levels ruminal ammonia- $\mathrm{N}$ concentrations declined steadily, reaching the lowest levels $(0.4 \mathrm{mg} / 100 \mathrm{~mL})$ at $9 \mathrm{~h}$ after the morning meal for the control treatment $(0 \mathrm{~g} / \mathrm{d})$. Supplementary urea-N infusions did not increase ruminal ammonia-N concentrations relative to the control treatment except for the highest level of infusion $(66 \mathrm{~g} / \mathrm{d})$. Lowest ruminal ammonia- $\mathrm{N}$ concentrations remained between 0.4 to $0.9 \mathrm{mg} / 100 \mathrm{~mL}$ for the urea- $\mathrm{N}$ infusion levels between 0 to $49 \mathrm{~g} / \mathrm{d}$ but for the highest level of urea- $\mathrm{N}$ infusion $(66 \mathrm{~g} / \mathrm{d})$ the lowest ammonia- $\mathrm{N}$ concentrations did not decrease below $2.2 \mathrm{mg} / 100 \mathrm{~mL}$ (Figure 1).
Irrespective of the urea- $\mathrm{N}$ infusion level, mean $\mathrm{ru}-$ men ammonia- $\mathrm{N}$ concentrations remained very low for lactating dairy cows (between 3.1 to $5.1 \mathrm{mg} / 100 \mathrm{~mL}$; Table 4). Nonetheless, urea- $\mathrm{N}$ had a curvilinear effect (quadratic effect, $P=0.01$ ) on rumen ammonia-N concentrations as no effects were observed for the lower levels (0 to $49 \mathrm{~g} / \mathrm{d}$ ), whereas for the highest level of urea-N infusion $(66 \mathrm{~g} / \mathrm{d})$ the ammonia-N concentrations sharply increased (Table 4). The curvilinear effect of supplementary urea- $\mathrm{N}$ is evident in the relationship between diet $\mathrm{CP}$ concentration and rumen ammonia- $\mathrm{N}$ concentrations (Figure 2). Urea-N infusion levels had no effect on rumen $\mathrm{pH}$, concentration of VFA in the

Table 3. Effects of urea infusion on milk production and composition

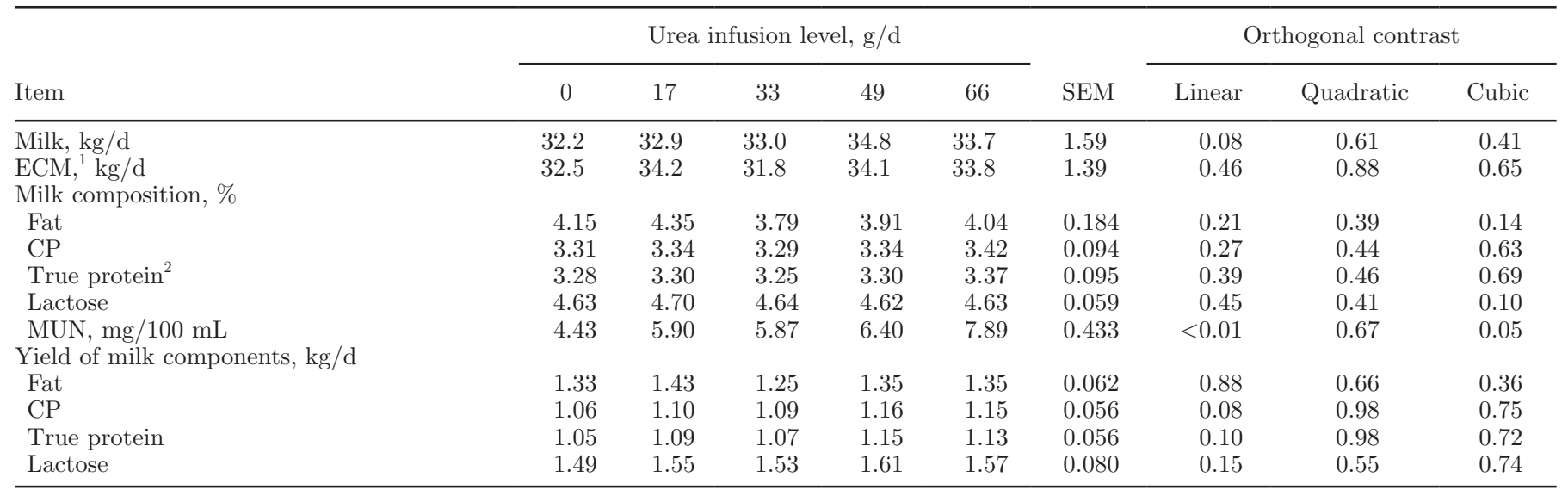

${ }^{1} \mathrm{ECM}=$ milk yield $\times(383 \times$ fat $\%+242 \times$ protein $\%+165.4 \times$ lactose $\%+20.7) / 3,140$ (Sjaunja et al., 1990).

${ }^{2}$ True protein $=\mathrm{CP} \%-($ milk urea nitrogen $\% \times 6.38)$. 


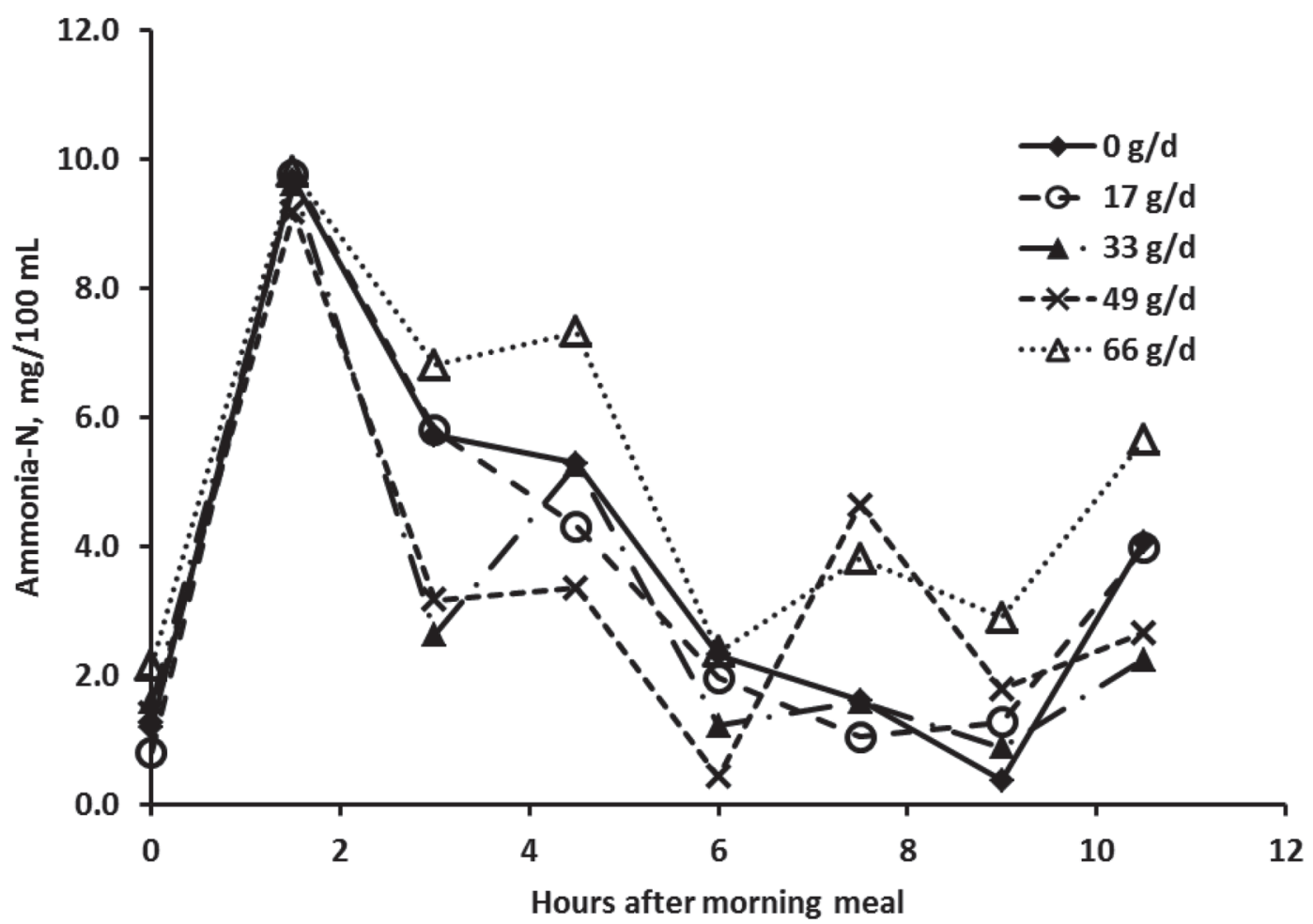

Figure 1. The effect of urea infusion level on diurnal pattern of ruminal ammonia-N concentrations $(\mathrm{mg} / 100 \mathrm{~mL})$.

rumen or the molar proportions of individual VFA with the exception of butyrate that decreased and the propionate:butyrate ratio that increased as the urea-N infusions levels increased (linear effects, $P=0.05$ ).

\section{Urea-N Utilization}

Nitrogen excretion in urine and feces exhibited consistent linear responses to urea- $\mathrm{N}$ infusion levels. When $\mathrm{N}$ intake was plotted against the amount of $\mathrm{N}$ excreted in urine, the slope indicated that proportionally $53 \%$ $\left(\mathrm{R}^{2}=0.94\right.$, Figure 3$)$ of $\mathrm{N}$ intake was excreted in urine. The relationship between $\mathrm{N}$ intake and true protein $\mathrm{N}$ output in milk suggests that proportionally $18 \%\left(\mathrm{R}^{2}\right.$ $=0.74$, Figure 4 ) of urea- $\mathrm{N}$ was used for milk protein synthesis. When the diet CP concentration is plotted against digestible $\mathrm{CP}$ concentration (Figure 5), the slope provides an estimate for true digestibility of supplementary $\mathrm{N}$ and the intercept represents an estimate for the amount of metabolic fecal CP excreted per unit

Table 4. Effects of urea infusion on rumen fermentation characteristics

\begin{tabular}{|c|c|c|c|c|c|c|c|c|c|}
\hline Item & \multicolumn{5}{|c|}{ Urea infusion level, $\mathrm{g} / \mathrm{d}$} & SEM & \multicolumn{3}{|c|}{ Orthogonal contrast } \\
\hline $\mathrm{pH}$ & 6.5 & 6.4 & 6.6 & 6.5 & 6.5 & 0.12 & 0.84 & 0.94 & 0.40 \\
\hline Total VFA, mmol/L & 115 & 118 & 113 & 118 & 119 & 2.6 & 0.38 & 0.45 & 0.58 \\
\hline \multicolumn{10}{|l|}{ Molar proportion of VFA, $\mathrm{mmol} / \mathrm{mol}$} \\
\hline Acetate & 647 & 629 & 642 & 642 & 637 & 7.2 & 0.78 & 0.58 & 0.10 \\
\hline Butyrate & 135 & 140 & 133 & 128 & 130 & 5.6 & 0.05 & 0.73 & 0.11 \\
\hline Isovalerate & 8.6 & 8.4 & 8.7 & 8.3 & 8.1 & 0.83 & 0.46 & 0.71 & 0.87 \\
\hline Valerate & 13.7 & 14.1 & 13.6 & 13.6 & 13.7 & 0.53 & 0.63 & 0.92 & 0.50 \\
\hline Caproate & 8.6 & 8.0 & 9.1 & 8.3 & 9.0 & 0.73 & 0.65 & 0.74 & 0.96 \\
\hline $\operatorname{Pr} / \mathrm{Bu}^{1}$ & 1.35 & 1.42 & 1.44 & 1.53 & 1.52 & 0.081 & 0.05 & 0.72 & 0.77 \\
\hline
\end{tabular}

${ }^{1}$ Propionate/butyrate. 


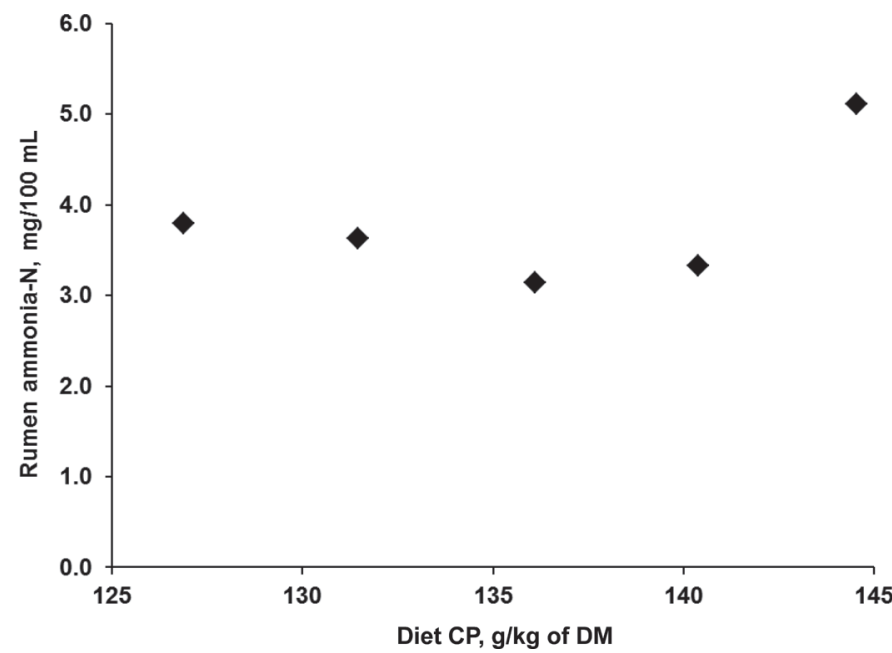

Figure 2. The relationship between $\operatorname{diet} \mathrm{CP}(\mathrm{g} / \mathrm{kg}$ of DM) and rumen ammonia-N concentrations $(\mathrm{mg} / 100 \mathrm{~mL})$.

of feed intake (Lucas test). The slope of the regression indicated true digestibility of 0.93 for supplementary $\mathrm{CP}$ intake and $39 \mathrm{~g}$ of metabolic fecal CP per kilogram of DMI.

\section{DISCUSSION}

\section{Nitrogen Utilization}

Dairy businesses are confronted with increasing pressures not only to be economically competitive but also to produce milk that is accepted as ecologically sustainable. To respond to these challenges, dairy nutritionists need reliable and readily available tools to control the daily ration in terms of adequate nutrient supply rela-

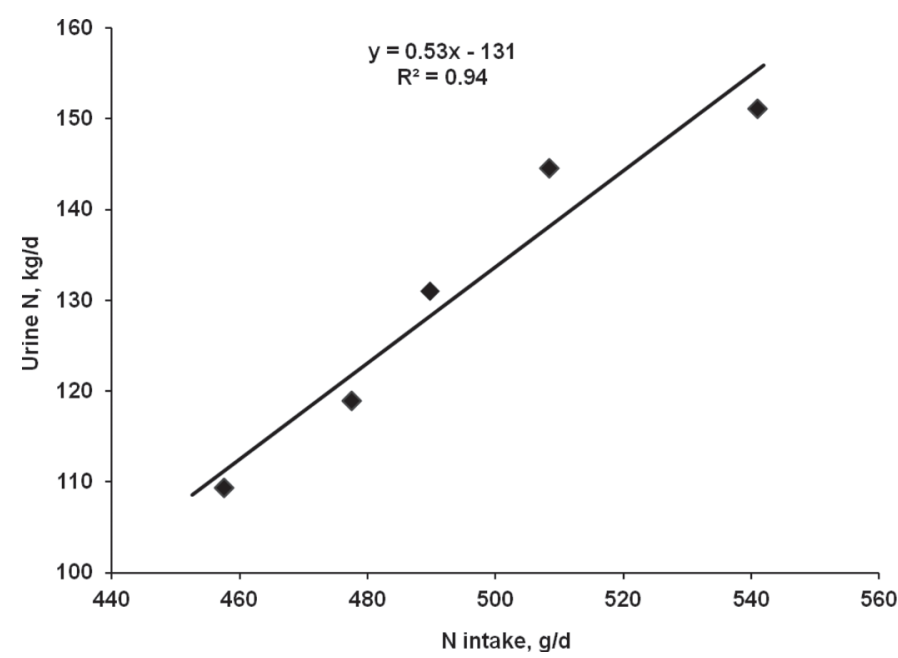

Figure 3. The effect of $\mathrm{N}$ intake $(\mathrm{g} / \mathrm{d})$ on the amount of $\mathrm{N}$ excreted in urine $(\mathrm{g} / \mathrm{d})$.

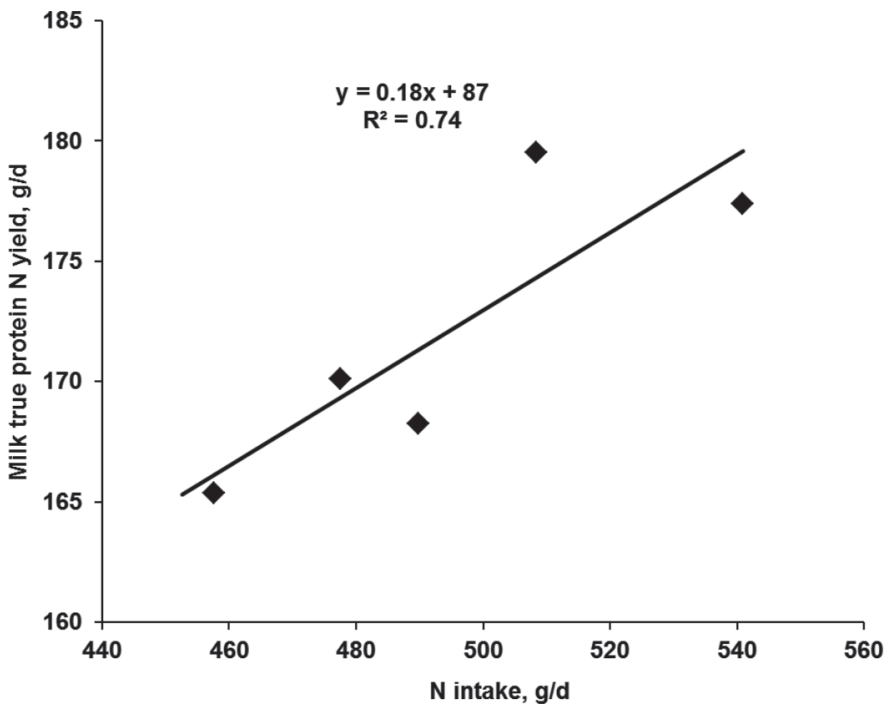

Figure 4. The effect of $\mathrm{N}$ intake $(\mathrm{g} / \mathrm{d})$ on the amount of true protein $\mathrm{N}$ output in milk $(\mathrm{g} / \mathrm{d})$

tive to cows' requirements. Ration $\mathrm{CP}$ and milk urea-N concentrations are simple diagnostic tools (Broderick and Clayton, 1997), but they have been somewhat overlooked because the current models have emphasized the role of RUP as a source of supplementary $\mathrm{MP}$, whereas RDP has been considered a homogeneous source of $\mathrm{N}$ for microbial protein synthesis without any distinction in effectiveness between NPN and true protein. However, previous studies have demonstrated that RDP from true protein sustains higher efficiency

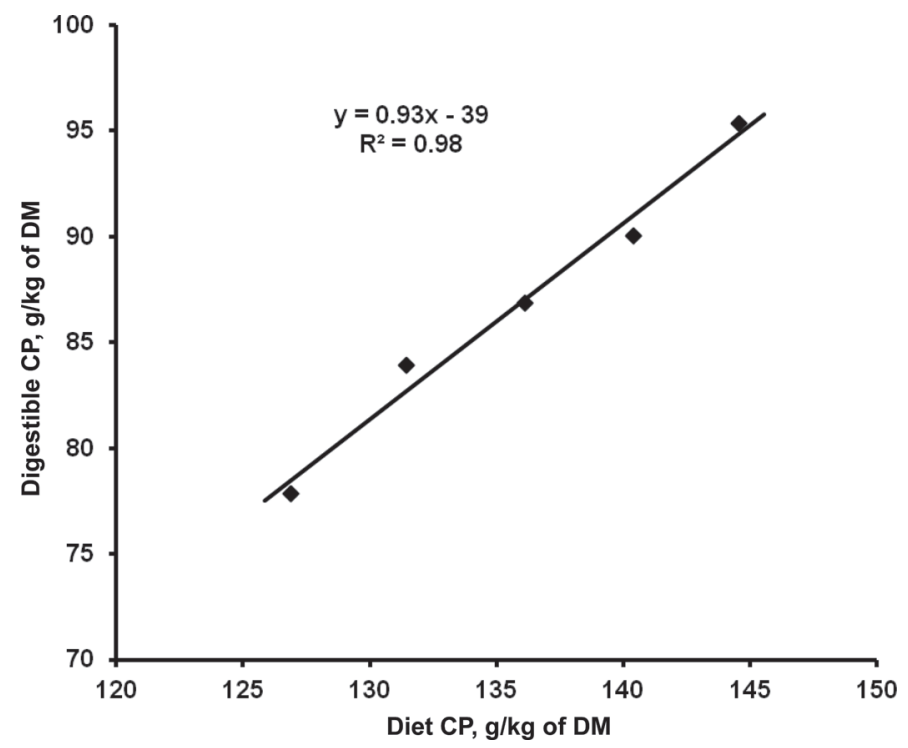

Figure 5. The plot of digestible $\mathrm{CP}$ concentration against dietary $\mathrm{CP}$ concentration to assess true $\mathrm{CP}$ digestibility of incremental $\mathrm{N}$ intake. 
of microbial protein synthesis than NPN (Broderick and Reynal, 2009). Critical evaluations of the current protein systems have suggested that the performance of complex approaches to predict MP intake may not be superior to simple systems based on $\mathrm{ME}$ and diet $\mathrm{CP}$ intake (Schwab et al., 2005).

In the current study the relationship between $\mathrm{N}$ intake and true protein $\mathrm{N}$ output in milk suggested $\mathrm{N}$ use efficiency of $18 \%$ for supplementary N. Although microbial $\mathrm{N}$ synthesis in the rumen was not currently measured, increases in milk true protein yield and fecal $\mathrm{N}$ output indicated that supplementary $\mathrm{N}$ was used by the rumen microbes. Assuming $80 \%$ of rumen microbial N entering the intestines is true protein, digestibility of this true protein is $80 \%$ (NRC, 2001), and the efficiency of MP use of for milk protein synthesis is $67 \%$ (NRC, 2001), the efficiency of microbial protein utilization for milk protein synthesis is $43 \%$. Assuming that in the current study $18 \%$ of supplementary urea- $\mathrm{N}$ was transferred to milk true protein $\mathrm{N}$, the proportion used by the rumen microbes $(0.18 / 0.43)$ suggests that $42 \%$ of urea- $\mathrm{N}$ was captured by the rumen microbes. This figure represents both immediate capture of urea- $\mathrm{N}$ to microbial $\mathrm{N}$ and recycled urea- $\mathrm{N}$ that re-entered the forestomach via the hepatic ornithine cycle. The current estimate of ruminal utilization of supplementary urea- $\mathrm{N}$ is in agreement with the mean values for urea- $\mathrm{N}$ kinetics estimated by Lapierre and Lobley (2001). These authors estimated that typically $33 \%$ of hepatic urea- $\mathrm{N}$ flux is eliminated in urine, whereas $67 \%$ enters the digestive tract. Of this latter, $50 \%$ is reabsorbed as anabolic- $\mathrm{N}$ (microbial $\mathrm{N}$ ), whereas $40 \%$ is reabsorbed as ammonia- $\mathrm{N}$ and $10 \%$ is lost in feces. However, the efficiency of urea recycling into the forestomach is dependent on the diet CP concentration as previously demonstrated by Kristensen et al. (2010). These authors observed a substantial increase in arterial urea extraction across the rumen wall when cows were switched from high $\mathrm{N}$ to low $\mathrm{N}$ diet (17.1 vs. $12.9 \% \mathrm{CP}$ ).

In the current study, one diet was offered to the animals and supplementary urea- $\mathrm{N}$ was provided directly into the rumen to avoid confounding effects due to changes in diet composition. Therefore, the Lucas test was expected to indicate $100 \%$ true digestibility for supplementary urea- $\mathrm{N}$ in case it was completely absorbed from the digestive tract without being used for microbial CP synthesis. Alternatively, in a case that the Lucas test suggested lower than $100 \%$ digestibility for urea- $\mathrm{N}$, it was expected to indicate microbial utilization of supplementary $\mathrm{N}$ because microbial cells are incompletely digested and increase fecal $\mathrm{N}$ excretion per unit of DMI. A linear increase in fecal CP concentrations was currently observed. The Lucas test indicated true digestibility of $93 \%$ for supplementary $\mathrm{N}$ and $39 \mathrm{~g} / \mathrm{kg}$ of DM for fecal metabolic CP. These figures are in line with true digestibilities between 92 to $96 \%$ and fecal metabolic CP between 26 to $39 \mathrm{~g} / \mathrm{kg}$ of DM estimated for supplementary protein provided as untreated canola meal, soybean mean, and the mixture of soybean and fishmeal (Huhtanen et al., 2011a). Similar total-tract digestibility estimates for urea- $\mathrm{N}$ and protein feeds provide evidence that supplementary urea- $\mathrm{N}$ was partly used for microbial $\mathrm{N}$ synthesis. If increases in $\operatorname{diet} \mathrm{CP}$ concentrations are attained by incremental urea- $\mathrm{N}$ infusion levels, the digestibility of supplementary $\mathrm{N}$ should be complete unless microbial $\mathrm{N}$ synthesis either in the rumen or in the hindgut (i.e., cecum and colon) is increased. Assuming $82 \%$ true digestibility for rumen microbial CP (Storm et al., 1983) and 100\% digestibility for the fraction of supplementary $\mathrm{N}$ that was not used for microbial N synthesis, an estimate of $39 \%$ for the proportion of urea- $\mathrm{N}$ captured by the rumen microbes is indicated. This estimate agrees with the value (42\%) estimated above based on the use of supplementary $\mathrm{N}$ for milk N synthesis. Albeit in good agreement, both estimates are based on several assumptions such that their accuracy should be regarded with caution.

The efficiency of urea-N use for milk true protein synthesis in the current study was higher $(18 \%)$ than the marginal milk protein yield responses $(\mathrm{g} / \mathrm{kg}$ increase in $\mathrm{CP}$ intake) estimated for rapeseed meal CP $(13.5 \%)$ or soybean meal CP $(10 \%)$ in a meta-analysis by Huhtanen et al. (2011a). An obvious reason for the high marginal responses to supplementary urea- $\mathrm{N}$ in the current study was the low dietary $\mathrm{CP}$ concentration because marginal responses in milk protein yield tend to decline as a linear function of diet $\mathrm{CP}$ concentration (55.63 g/d - $2.52 \mathrm{~g} / \mathrm{d} \times \mathrm{CP} \%$; NRC, 2001). Replacement of corn with soybean meal in dairy cow ration increased diet CP concentration from 135 to $165 \mathrm{~g} / \mathrm{kg}$ of DM and improved milk protein yield with a marginal efficiency of $98 \mathrm{~g} / \mathrm{kg}$ increase in CP intake (Olmos Colmenero and Broderick, 2006). However, further increases in the amount of soybean meal failed to improve milk protein yield. The diminishing returns often observed in protein supplementation studies can be attributed, at least partly, to poor utilization of excess ammonia$\mathrm{N}$ released from ruminal protein degradation at high diet $\mathrm{CP}$ concentrations. Excess ammonia- $\mathrm{N}$ is absorbed from the digestive tract into plasma, converted to urea in the liver, recycled back into the gut or filtered from plasma by the kidneys, and excreted in urine (Lobley et al., 2000). The fractional transfer rate of urea into the gut is dependent on the diet CP concentration such that at low CP concentrations higher proportions of plasma urea are recycled into the gut and used for mi- 
crobial synthesis, whereas at high $\mathrm{CP}$ concentrations higher proportions of plasma urea are eliminated from the body in urine (Wickersham et al., 2008).

Previous findings have suggested that plasma urea transport across the gut epithelia is directly proportional to plasma urea concentrations but also affected by the nutritional status of the animal such that epithelial gut permeability decreases with increasing $\mathrm{N}$ status of the animal (Kristensen et al., 2010). Wickersham et al. (2008) studied the effects of incremental casein in steers fed low-quality prairie hay (CP $47 \mathrm{~g} / \mathrm{kg}$ of DM). The proportion of plasma urea entering the gut decreased linearly from 98 to $83 \%$ and the proportion of gut urea-N used by the microbes decreased from 51 to $42 \%$ as the diet CP concentration increased from 55 to $91 \mathrm{~g} / \mathrm{kg}$ of DM by supplementary casein that provided 7.0 to $65.3 \mathrm{~g} / \mathrm{d}$ of $\mathrm{N}$. In dairy heifers fed isocaloric diets, increasing the CP from 91 to $213 \mathrm{~g} / \mathrm{kg}$ of DM increased the proportion of the urea- $\mathrm{N}$ synthesized in the body that is excreted as urinary urea-N from 15 to $71 \%$ and decreased the proportion of $\mathrm{N}$ recycled into the gut that was used for microbial protein synthesis from 43 to $6 \%$ (Marini and Van Amburgh, 2003). These observations clearly indicate a strong influence of the diet CP concentration on the efficiency of urea recycling and help to explain the high efficiency of supplementary urea-N use observed in the current study.

\section{Rumen Ammonia-N Concentration}

In the current study rumen ammonia- $\mathrm{N}$ concentrations were determined based on 12-h sampling period covering the hours between 0600 and 1800 h. Hence, it is assumed that these measurements represent the entire 24-h period. To minimize differences in feed intake pattern between day and night time periods, cows were fed at 0600, 0900, 1800, and $2000 \mathrm{~h}$. In the current study rumen ammonia-N concentrations did not exhibit responses to urea- $\mathrm{N}$ infusion until the highest level of urea- $\mathrm{N}$ was reached. At the lower levels of urea$\mathrm{N}$ infusion (0 to $49 \mathrm{~g} / \mathrm{d}$ ) the average rumen ammonia- $\mathrm{N}$ concentrations remained between 3.1 and $3.8 \mathrm{mg} / 100$ $\mathrm{mL}$. This pattern of rumen ammonia- $\mathrm{N}$ responses tends to suggest that rumen microbes efficiently captured supplementary ammonia-N until sufficient intracellular ammonia-N concentration was reached. Consistent with this interpretation, Russell and Strobel (1987) observed higher intracellular than extracellular ammonia$\mathrm{N}$ concentrations in mixed rumen bacteria indicative of active ammonia- $\mathrm{N}$ transport mechanisms possessed by rumen bacteria. The ammonia-N gradient between extracellular and intracellular space was highest at the low rumen ammonia- $\mathrm{N}$ concentrations because bacteria were able to maintain a minimum of $13 \mathrm{mg} / 100 \mathrm{~mL}$ intracellular ammonia- $\mathrm{N}$ concentrations (Russell and Strobel, 1987). The minimum extracellular ammonia-N concentrations (1.0 mg/100 mL) observed by Russell and Strobel (1987) suggested that despite an active transport system rumen bacteria could not completely deplete ammonia- $\mathrm{N}$ from the extracellular environment. In contrast to these findings observed in vitro, the lowest ammonia- $\mathrm{N}$ concentrations in the current study recorded for each individual animal were not more than $0.1 \mathrm{mg} / 100 \mathrm{~mL}$. Consistent with our results, Marini and Van Amburgh (2003) observed hardly detectable rumen ammonia- $\mathrm{N}$ concentrations (average $0.1 \mathrm{mg} / 100$ $\mathrm{mL}$ ) in Holstein heifers fed a diet with $91 \mathrm{~g} / \mathrm{kg}$ DM of CP. Hence, it seems evident that mixed rumen bacteria are capable of efficiently depleting ammonia- $\mathrm{N}$ from rumen fluid when the rate of ammonia- $\mathrm{N}$ release from protein degradation and microbial turnover is lower than microbial uptake. Owing to the active ammonia-N transport systems present in the rumen microbial community, low extracellular ammonia- $\mathrm{N}$ concentrations may be an inadequate indicator of microbial intracellular concentrations.

In the current study, an inflection point in the rumen ammonia- $\mathrm{N}$ concentrations was achieved at a diet CP concentration of $140 \mathrm{~g} / \mathrm{kg} \mathrm{DM}(49 \mathrm{~g} / \mathrm{d}$ of urea-N). Above this CP concentration extracellular ammonia-N concentrations sharply increased. In a study conducted using steers (Slyter et al., 1979) the response of ruminal ammonia-N concentration to increasing amounts of urea-N infusions into the rumen exhibited a smaller slope between 80 to $169 \mathrm{~g} / \mathrm{kg} \mathrm{DM}$ of CP followed by a steeper slope for ammonia-N concentrations between 169 to $195 \mathrm{~g} / \mathrm{kg}$ DM of CP. In the study of Marini and Van Amburgh (2003) increases in ruminal ammonia-N concentrations were 3.3 times greater between 118 to $186 \mathrm{~g}$ of $\mathrm{CP} / \mathrm{kg}$ of $\mathrm{DM}$ than between 91 to $118 \mathrm{~g}$ of $\mathrm{CP} / \mathrm{kg}$ of DM. These observations could be explained by efficient uptake of rumen ammonia- $\mathrm{N}$ into microbial cells until the requirements for optimal growth were achieved. Beyond this point, the rate of ammonia-N release from ruminal protein degradation exceeded the rate of anabolic requirements and ammonia- $\mathrm{N}$ started to accumulate in rumen fluid. Considering the curvilinear response in ruminal ammonia- $\mathrm{N}$ concentration currently observed, it was somewhat unexpected that the proportion of supplementary urea-N excreted in urine was constant throughout. This could be related to alleged increases in intracellular ammonia-N pool (Russell and Strobel, 1987) that escaped the rumen in microbial $\mathrm{N}$ entering the intestines and was absorbed from the intestines, and subsequently excreted in urine.

In the current study, supplementary urea- $\mathrm{N}$ had no significant effects on NDF digestibility in spite of very low extracellular ammonia-N concentrations. Slyter 
et al. (1979) concluded that near maximum DM and fiber digestibility were attained when the diet $\mathrm{CP}$ concentration was $95 \mathrm{~g} / \mathrm{kg}$ of $\mathrm{DM}$ and the average rumen ammonia-N concentration was $1.1 \mathrm{mg} / 100 \mathrm{~mL}$. Marini and Van Amburgh (2003) observed a reduction in fiber digestibility at a diet CP concentration of $91 \mathrm{~g} / \mathrm{kg}$ of $\mathrm{DM}$ and ruminal ammonia- $\mathrm{N}$ concentration of 0.1 $\mathrm{mg} / 100 \mathrm{~mL}$. However, no further improvements in digestibility were achieved beyond diet $\mathrm{CP}$ concentration of $118 \mathrm{~g} / \mathrm{kg}$ of DM and ruminal ammonia-N concentration of $1.7 \mathrm{mg} / 100 \mathrm{~mL}$. These observations suggest that diet digestibility is not likely to be compromised unless a diet with very low concentration of $\mathrm{CP}$ is offered, whereas rumen ammonia- $\mathrm{N}$ concentrations above 1 $\mathrm{mg} / 100 \mathrm{~mL}$ seem sufficient for optimal diet digestibility. However, in contrast to these conclusions a previous meta-analysis of 497 diets indicated a consistent positive relationship between diet $\mathrm{CP}$ concentration and NDF digestibility (Nousiainen et al., 2009). In that meta-analysis, NDF digestibility increased by $7.7 \mathrm{~g} / \mathrm{kg}$ per 1-percentage-unit increase in diet $\mathrm{CP}$ concentration. In the current study, lack of response in NDF digestibility to urea- $\mathrm{N}$ infusions may be due to lack of statistical power in a single experiment because the slope of regression between diet $\mathrm{CP}$ concentration and NDF digestibility was $6.6 \mathrm{~g} / \mathrm{kg}$ per 1-percentage-unit increase in diet $\mathrm{CP}$ concentration.

Broderick et al. (2010) concluded, based on a meta-analysis of 32 studies, that the omasal canal nonammonia- $\mathrm{N}$ flows were equal to $\mathrm{N}$ intake at diet $\mathrm{CP}$ concentration of $147 \mathrm{~g} / \mathrm{kg}$ of $\mathrm{DM}$ and ruminal ammonia-N concentration of 7.1 and MUN concentration of $8.3 \mathrm{mg} / 100 \mathrm{~mL}$. Under those circumstances, and assuming a steady state, there is no net absorption of ammonia- $\mathrm{N}$ from the rumen and the amount of $\mathrm{CP}$ degraded in the rumen per unit of time equals microbial $\mathrm{CP}$ synthesis. Consistent with these estimates, Castillo et al. (2001) noted an exponential increase in urinary $\mathrm{N}$ excretion of dairy cows above diet $\mathrm{CP}$ concentrations of $140 \mathrm{~g} / \mathrm{kg}$ of DM. In a summary of several studies, Schwab et al. (2005) concluded that ammonia-N concentrations between 7 to $15 \mathrm{mg} / 100 \mathrm{~mL}$ were needed to maximize microbial $\mathrm{N}$ flow from the rumen. Based on in vitro studies, Russell and Strobel (1987) concluded that at least $50 \mathrm{mg}$ of ammonia/L $(4.1 \mathrm{mg} / 100 \mathrm{~mL}$ of ammonia-N) was needed to maximize bacterial protein synthesis. In the current study, based on the abovementioned criteria, ruminal ammonia- $\mathrm{N}$ concentrations were suboptimal for the maximum rate of microbial-N synthesis on all urea- $\mathrm{N}$ infusion levels. As estimated above, despite low ruminal ammonia- $\mathrm{N}$ concentrations, rumen microbes captured approximately $40 \%$ of supplementary urea-N, but eventually the major proportion $(53 \%)$ of supplementary urea-N was excreted in urine.
These observations tend to suggest that even under limiting conditions rumen microbes cannot completely utilize supplementary ammonia-N.

Once absorbed from the gut, ammonia- $\mathrm{N}$ will be eliminated in urine unless recycled into the gastrointestinal tract. The efficiency of urea- $\mathrm{N}$ recycling and the contribution of recycled urea- $\mathrm{N}$ to microbial $\mathrm{N}$ synthesis are dependent not only on plasma urea and rumen ammonia concentrations but also on the permeability of gut epithelia that is affected by the $\mathrm{N}$ status of the animal (Kennedy and Milligan, 1980; Kristensen et al., 2010). The effects of diet composition on the efficiency of urea- $\mathrm{N}$ recycling seem to be associated with adaptive changes in animal physiology. In studies with dry cows, Bailey and Balch (1961) observed a linear relationship between saliva and plasma urea concentrations with saliva concentrations being $65 \%$ of those in plasma. Based on a series of experiments in steers employing radionuclide tracer techniques, Kennedy (1980) concluded that urea-N entering the rumen in saliva was dependent on plasma urea concentrations but independent of rumen ammonia- $\mathrm{N}$ concentration. In contrast, the direct transfer of plasma urea from capillaries through the rumen wall into the rumen was positively related to plasma urea and negatively to rumen ammonia-N concentrations (Kennedy, 1980). In addition, increases in the rate of rumen fermentation and microbial energy supply seem to enhance the transfer of plasma urea into the gut. Supplementation of forage diets with sucrose increased the rate of plasma entry into the gut of steers by $35 \%$ (Kennedy, 1980). Kennedy and Milligan (1980) pointed out an inverse relationship between urea transfer from plasma to the rumen and rumen ammonia- $\mathrm{N}$ concentration in sheep and cattle. This negative relationship decreases the contribution of recycled urea- $\mathrm{N}$ to microbial $\mathrm{N}$ synthesis and partly explains the diminishing returns to supplementation of a diet with protein feeds.

\section{Milk Urea Nitrogen}

If diet $\mathrm{CP}$ concentration can be readily and reliably determined on farm it is a good predictor of $\mathrm{N}$ use efficiency for milk protein synthesis (Huhtanen and Hristov, 2009). Milk urea- $\mathrm{N}$ concentration is primarily dependent on diet $\mathrm{CP}$ concentration and can be used to predict the $\mathrm{N}$ use efficiency, rumen $\mathrm{N}$ balance, and urine $\mathrm{N}$ excretion in dairy cows (Broderick and Clayton, 1997; Nousiainen et al., 2004). However, Spek et al. (2013) identified several factors influencing the relationship between MUN concentrations and urinary urea- $\mathrm{N}$ excretion in dairy cattle. Milk urea-N concentrations are affected by factors such as the time of milk sampling relative to feed intake pattern, water intake 
and diet mineral concentrations, feeding and milking frequency, and analytical methods (enzymatic vs. infrared spectrometry).

Considering MUN as a diagnostic tool for an adequate diet $\mathrm{CP}$ concentration, it is noteworthy that in the current study MUN responded to increases in supplementary urea in a more consistent manner than the rumen ammonia- $\mathrm{N}$ concentrations. In agreement with these observations Broderick and Clayton (1997) reported a closer relationship between MUN and diet $\mathrm{CP}$ concentration $\left(\mathrm{CP} \%=0.269 \times \mathrm{MUN}+13.7 ; \mathrm{R}^{2}\right.$ $=0.84)$ than between MUN and ruminal ammonia- $\mathrm{N}$ $\left(\mathrm{NH}_{3}, \mathrm{mg}\right.$ of $\mathrm{N} / 100 \mathrm{~mL}=0.686 \times \mathrm{MUN}+6.43 ; \mathrm{R}^{2}$ $=0.57$ ). Increases in postruminal $\mathrm{N}$ supply provided as casein infused into the abomasum increased plasma urea- $\mathrm{N}$ and MUN concentration but did not have effects on rumen ammonia- $\mathrm{N}$ concentrations (Vanhatalo et al., 2003). Urea-N concentrations in milk and plasma are closely correlated (Broderick and Clayton, 1997) but also exhibit diurnal variation that reflects ruminal pattern of ammonia-N concentrations with 1.5 to $2 \mathrm{~h}$ lag between rumen ammonia- $\mathrm{N}$ and blood urea-N and about $1 \mathrm{~h}$ lag between blood urea-N and MUN (Gustafsson and Palmquist, 1993). If dairy cow diets are to be formulated solely based on diet CP concentration rather than based on distinct requirements for RDP and RUP there should be a close relationship between diet $\mathrm{CP}$ concentration and plasma urea concentration. The slope of the relationship between diet CP concentration and MUN in the current study $[\operatorname{MUN}(\mathrm{mg} / 100 \mathrm{~mL})=-16.9+0.17 \times \operatorname{diet} \mathrm{CP}(\mathrm{g} /$ $\mathrm{kg}$ of DM)] was similar to that reported by Nousiainen et al. (2004) based on 50 production trials with 306 treatment means $[\mathrm{MUN}(\mathrm{mg} / 100 \mathrm{~mL})=-14.2+0.17$ $\times \operatorname{diet} \mathrm{CP}(\mathrm{g} / \mathrm{kg}$ of $\mathrm{DM})]$. A potential explanation for the smaller intercept estimated for the current study than reported by Nousiainen et al. (2004) might be the high digestibility and good fermentation quality of grass silage used in the current study. When cows were offered either early $(714 \mathrm{~g} / \mathrm{kg}$ of DM of digestible OM) or late harvested grass silage $(673 \mathrm{~g} / \mathrm{kg}$ of DM of digestible OM) observed MUN was $0.4 \mathrm{mg} / 100 \mathrm{~mL}$ lower than that predicted based on diet $\mathrm{CP}$ concentration for the early harvested and $0.9 \mathrm{mg} / 100 \mathrm{~mL}$ higher than predicted for the late harvested grass silage (Kuoppala et al., 2009, 2010).

\section{CONCLUSIONS}

The results from the current study indicate that dairy cows offered a diet slightly deficient with respect to RUP benefit from supplementary RDP provided as urea-N. However, quantitatively the effects were small and cows did not show any acute signs of deficiency but adapted well to the basal diet despite very low rumen ammonia- $\mathrm{N}$ and milk urea- $\mathrm{N}$ concentrations. The efficiency of $\mathrm{N}$ utilization tended to decrease in a linear manner with increases in supplementary urea-N. Eighteen percent of supplementary urea- $\mathrm{N}$ infused into the rumen was secreted in milk, whereas the remainder was excreted in urea and feces. Milk urea-N concentrations responded to increases in intraruminal $\mathrm{N}$ supply in a consistent manner, whereas rumen ammonia-N concentrations increased only at the highest level of urea- $\mathrm{N}$ infusion.

\section{ACKNOWLEDGMENTS}

This study received funding from the European Union's Horizon 2020 research and innovation program under grant agreement no. 696356. Funding was provided by the Finnish Ministry of Agriculture and Forestry as part of the RumenPredict project (Predicting appropriate GHG mitigation strategies based on modelling variable that contribute to ruminal environmental impact; Project code 4400T-1003).

\section{REFERENCES}

Ahvenjärvi, S., E. Joki-Tokola, A. Vanhatalo, S. Jaakkola, and P. Huhtanen. 2006. Effects of replacing grass silage with barley silage in dairy cow diets. J. Dairy Sci. 89:1678-1687.

Ahvenjärvi, S., M. Vaga, A. Vanhatalo, and P. Huhtanen. 2018. Ruminal metabolism of grass silage soluble nitrogen fractions. J. Dairy Sci. 101:279-294.

AOAC International. 2012. Official Methods of Analysis. 19th ed. AOAC International, Gaithersburg, MD.

Bailey, C. B., and C. C. Balch. 1961. Saliva secretion and it's relation to feeding in cattle. 2. The composition and rate of secretion of mixed saliva in the cow during rest. Br. J. Nutr. 15:383-402.

Broderick, G. A. 2003. Effects of varying dietary protein and energy levels on the production of lactating dairy cows. J. Dairy Sci. $86: 1370-1381$

Broderick, G. A., and M. K. Clayton. 1997. A statistical evaluation of animal and nutritional factors influencing concentrations of milk urea nitrogen. J. Dairy Sci. 80:2964-2971.

Broderick, G. A., P. Huhtanen, S. Ahvenjärvi, S. M. Reynal, and K. J. Shingfield. 2010. Quantifying ruminal nitrogen metabolism using the omasal sampling technique in cattle-A meta-analysis. J. Dairy Sci. 93:3216-3230.

Broderick, G. A., and S. M. Reynal. 2009. Effect of source of rumendegraded protein on production and ruminal metabolism in lactating dairy cows. J. Dairy Sci. 92:2822-2834.

Castillo, A. R., E. Kebreab, D. E. Beever, J. H. Barbi, J. D. Sutton, H. C. Kirby, and J. France. 2001. The effect of protein supplementation on nitrogen utilization in lactating dairy cows fed grass silage diets. J. Anim. Sci. 79:247-253.

Choung, J. J., and D. G. Chamberlain. 1993. The effects of abomasal infusions of casein or soya-bean-protein isolate on the milk production of dairy cows in mid-lactation. Br. J. Nutr. 69:103-115.

Finnish Feed Tables and Nutrient Requirements. 2018. Rehutaulukot ja ruokintasuositukset. Accessed Feb. 21, 2018. https://portal.mtt .fi/portal/page/portal/Rehutaulukot.

Guinard, J., H. Rulquin, and R. Vérité. 1994. Effect of graded levels of duodenal infusions of casein on mammary uptake in lactating cows. 1. Major nutrients. J. Dairy Sci. 77:2221-2231. 
Gustafsson, A. H., and D. L. Palmquist. 1993. Diurnal variation of rumen ammonia, serum urea, and milk urea in dairy cows at high and low yields. J. Dairy Sci. 76:475-484.

Haacker, K., H. J. Block, and F. Weissbach. 1983. Zur kolorimetrischen Milchsäurebestimmung in Silagen mit p-Hydroxydiphenyl. Arch. Tierernahr. 33:505-512.

Huhtanen, P., and A. N. Hristov. 2009. A meta-analysis of the effects of dietary protein concentration and degradability on milk protein yield and milk N efficiency in dairy cows. J. Dairy Sci. 92:3222-3232.

Huhtanen, P., J. Nousiainen, and M. Rinne. 2006. Recent developments in forage evaluation with special reference to practical applications. Agric. Food Sci. 15:293-323.

Huhtanen, P., M. Rinne, P. Mäntysaari, and J. Nousiainen. 2011b. Integration of the effects of animal and dietary factors on total dry matter intake of dairy cows fed silage-based diets. Animal 5:691-702.

Huhtanen, P. H., M. Hetta, and C. Swensson. 2011a. Evaluation of canola meal as a protein supplement for dairy cows: A review and a meta-analysis. Can. J. Anim. Sci. 91:529-543.

Huhtanen, P. J., R. Blauwiekel, and I. Saastamoinen. 1998. Effects of intraruminal infusions of propionate and butyrate with two different protein supplements on milk production and blood metabolites in dairy cows receiving grass silage-based diet. J. Sci. Food Agric. $77: 213-222$.

Huida, L., H. Väätäinen, and M. Lampila. 1986. Comparison of dry matter contents in grass silages as determined by oven drying and gas chromatographic water analysis. Ann. Agric. Fenn. 25:215-230.

Ipharraguerre, I. R., and J. H. Clark. 2005. Impacts of the source and amount of crude protein on the intestinal supply of nitrogen fractions and performance of dairy cows. J. Dairy Sci. 88:E22-E37.

Kennedy, P. M. 1980. The effects of dietary sucrose and the concentration of plasma urea and rumen ammonia on the degradation of urea in the gastrointestinal tract of cattle. Br. J. Nutr. 43:125-140.

Kennedy, P. M., and L. P. Milligan. 1980. The degradation and utilization of endogenous urea in the gastrointestinal tract of ruminants: a review. Can. J. Anim. Sci. 60:205-221.

Kristensen, N. B., A. C. Storm, and M. Larsen. 2010. Effect of dietary nitrogen content and intravenous urea infusion on ruminal and portal-drained visceral extraction of arterial urea in lactating Holstein cows. J. Dairy Sci. 93:2670-2683.

Kuoppala, K., S. Ahvenjärvi, M. Rinne, and A. Vanhatalo. 2009. Effects of feeding grass or red clover silage cut at two maturity stages in dairy cows. 2. Dry matter intake and cell wall digestion kinetics. J. Dairy Sci. 92:5634-5644.

Kuoppala, K., M. Rinne, S. Ahvenjärvi, J. Nousiainen, and P. Huhtanen. 2010. The effect of harvesting strategy of grass silage on digestion and nutrient supply in dairy cows. J. Dairy Sci. 93:3253-3263.

Lapierre, H., and G. E. Lobley. 2001. Nitrogen recycling in the ruminant: A review. J. Dairy Sci. 84:E223-E236.

Lobley, G. E., D. M. Bremner, and G. Zuur. 2000. Effects of diet quality on urea fates in sheep as assessed by refined, non-invasive [15N15N]urea kinetics. Br. J. Nutr. 84:459-468.

Marini, J. C., and M. E. Van Amburgh. 2003. Nitrogen metabolism and recycling in Holstein heifers. J. Anim. Sci. 81:545-552.

McCullough, H. 1967. The determination of ammonia in whole blood by direct colorimetric method. Clin. Chim. Acta 17:297-304.

Nousiainen, J., M. Rinne, M. Hellämäki, and P. Huhtanen. 2003. Prediction of the digestibility of the primary growth of grass silages harvested at different stages of maturity from chemical composition and pepsin-cellulase solubility. Anim. Feed Sci. Technol. 103:97-111.

Nousiainen, J., M. Rinne, and P. Huhtanen. 2009. A meta-analysis of feed digestion in dairy cows. 1. The effects of forage and concentrate factors on total diet digestibility. J. Dairy Sci. 92:5019-5030.

Nousiainen, J., K. J. Shingfield, and P. Huhtanen. 2004. Evaluation of milk urea nitrogen as a diagnostic of protein feeding. J. Dairy Sci. 87:386-398.

NRC. 2001. Nutrient Requirements of Dairy Cattle. 7th rev. ed. Natl. Acad. Press, Washington, DC.

Nursoy, H., M. Gonzalez Ronquillo, A. P. Faciola, and G. A. Broderick. 2018. Lactation response to soybean meal and rumen-protected methionine supplementation of corn silage-based diets. J. Dairy Sci. 101:2084-2095.

Olmos Colmenero, J. J., and G. A. Broderick. 2006. Effect of dietary crude protein concentration on milk production and nitrogen utilization in lactating dairy cows. J. Dairy Sci. 89:1704-1712.

Russell, J. B., and H. J. Strobel. 1987. Concentration of ammonia across cell membranes of mixed rumen bacteria. J. Dairy Sci. 70:970-976.

Salo, M.-L., and M. Salmi. 1968. Determination of starch by the amyloglucosidase method. J. Sci. Agric. Soc. Finl. 40:38-45.

Schwab, C. G., P. Huhtanen, C. W. Hunt, and T. Hvelplund. 2005. Nitrogen requirements of cattle. Pages 13-70 in Nitrogen and Phosphorus Nutrition of Cattle. Reducing the Environmental Impact of Cattle Operations. E. Pfeffer and A. N. Hristov, ed. CABI Publishing, Wallingford, UK.

Sjaunja, L. O., L. Baevre, L. Junkkarinen, J. Pedersen, and J. Setälä. 1990. A Nordic proposal for an energy corrected milk (ECM) formula. Pages 156-157 in 27th Session International Committee of Recording and Productivity of Milk Animals, Paris, France.

Slyter, L. L., L. D. Satter, and D. A. Dinius. 1979. Effect of ruminal ammonia concentration on nitrogen utilization by steers. J. Anim. Sci. 48:906-912.

Somogyi, M. 1945. A new reagent for the determination of sugars. J. Biol. Chem. 160:61-68

Spek, J. W., J. Dijkstra, G. Van Duinkerken, and A. Bannink. 2013. A review of factors influencing milk urea concentration and its relationship with urinary urea excretion in lactating dairy cattle. J. Agric. Sci. 151:407-423.

Storm, E., D. S. Brown, and E. R. Ørskov. 1983. The nutritive value of rumen micro-organisms in ruminants 3 . The digestion of microbial amino and nucleic acids in, and losses of endogenous nitrogen from, the small intestine of sheep. Br. J. Nutr. 50:479-485.

Van Soest, P. J., J. B. Robertson, and B. A. Lewis. 1991. Methods for dietary fiber, neutral detergent fiber, and nonstarch polysaccharides in relation to animal nutrition. J. Dairy Sci. 74:3583-3597.

Vanhatalo, A., T. Varvikko, and P. Huhtanen. 2003. Effects of casein and glucose on responses of cows fed diets based on restrictively fermented grass silage. J. Dairy Sci. 86:3260-3270.

Vérité, R., and L. Delaby. 2000. Relation between nutrition, performances and nitrogen excretion in dairy cows. Ann. Zootech. $49: 217-230$.

Wickersham, T. A., E. C. Titgemeyer, R. C. Cochran, E. E. Wickersham, and E. S. Moore. 2008. Effect of frequency and amount of rumen-degradable intake protein supplementation on urea kinetics and microbial use of recycled urea in steers consuming low-quality forage. J. Anim. Sci. 86:3089-3099. 